\title{
介孔氧化铝复合材料负载铂催化剂上丙酮酸乙酯的不对称氢化反应
}

\author{
王海红, 王红娜, 李晓红 ${ }^{*}$, 王一萌, 吴 鹏 \\ 华东师范大学化学系, 上海市绿色化学与化工过程绿色化重点实验室, 上海 200062
}

\begin{abstract}
摘要: 采用固相研磨法制备了有序介孔树脂 FDU-14 孔道限阈分散的 $\mathrm{Al}_{2} \mathrm{O}_{3}$ 复合材料 $\mathrm{Al}_{2} \mathrm{O}_{3} @ \mathrm{FDU}-14$. 以其为载体, 采用浸渍 法制备了 $4.0 \% \mathrm{Pt}_{\mathrm{Al}} \mathrm{Al}_{2} \mathrm{O}_{3} @ \mathrm{FDU}-14$ 催化剂, 并利用 $\mathrm{X}$ 射线衍射、透射电子显微镜和 $\mathrm{N}_{2}$ 吸附等手段对催化剂进行了表征. 结果表 明, $\mathrm{Pt} / \mathrm{Al}_{2} \mathrm{O}_{3} @ \mathrm{FDU}-14$ 催化剂保持了 FDU-14 的介孔结构特征. 经手性分子辛可尼定修饰后, 考察了该催化剂在丙酮酸乙酯不 对称氢化反应中的催化性能. 当复合材料载体中 $\mathrm{Al}_{2} \mathrm{O}_{3}$ 含量为 $5 \% \sim 15 \%$ 时, $\mathrm{Al}_{2} \mathrm{O}_{3}$ 主要以无定形态均匀分布于 $\mathrm{FDU}-14$ 孔道内. 随着催化剂中 $\mathrm{Al}_{2} \mathrm{O}_{3}$ 含量增加, 丙酮酸乙醌不对称氢化反应的活性和产物的光学选择性都有所提高, 其中后者最高可达 $80 \%$ ee. $\mathrm{Al}_{2} \mathrm{O}_{3}$ 的引入可降低 FDU-14 介孔树脂材料表面的电子密度, 有利于辛可尼定在催化剂表面的吸附, 因此, $\mathrm{Pt}^{\mathrm{A}} / \mathrm{Al}_{2} \mathrm{O}_{3} @$ FDU-14 催化剂手性诱导能力比 Pt/FDU-14 强.
\end{abstract}

关键词：铂; 辛可尼定; 丙酮酸乙酯; 不对称氢化; 有序介孔树脂材料; 介孔氧化铝复合材料

中图分类号: 0643 文献标识码: A

收稿日期: 2011-06-07. 接受日期: 2011-08-10.

*通讯联系人. 电话/传真: (021)62238590; 电子信箱: xhli@chem.ecnu.edu.cn

基金来源：国家自然科学基金 (20703018); 上海市科委青年科技启明星人才计划 (08QA1402700); 国家重点基础研究发展计 划 (973 计划, 2006CB202508).

本文的英文电子版(国际版)由Elsevier出版社在ScienceDirect上出版(http://www.sciencedirect.com/science/journal/18722067).

\section{Asymmetric Hydrogenation of Ethyl Pyruvate on Chirally Modified Pt Catalysts Supported on $\mathrm{Al}_{2} \mathrm{O}_{3} @ F D U-14$ Mesoporous Composites}

\author{
WANG Haihong, WANG Hongna, LI Xiaohong ${ }^{*}$, WANG Yimeng, WU Peng \\ Shanghai Key Laboratory of Green Chemistry and Chemical Processes, Department of Chemistry, East China Normal University, \\ Shanghai 200062, China
}

\begin{abstract}
A series of $\mathrm{Al}_{2} \mathrm{O}_{3} @ \mathrm{FDU}-14$ composites with different alumina loadings were prepared using a solid state grinding method. The 4\% Pt catalysts supported on $\mathrm{Al}_{2} \mathrm{O}_{3} @$ FDU-14 were prepared by impregnation using $\mathrm{H}_{2} \mathrm{PtCl}_{6}$. X-ray diffraction, transmission electron microscopy, and nitrogen adsorption characterization of the $\mathrm{Pt} / \mathrm{Al}_{2} \mathrm{O}_{3} @ \mathrm{FDU}-14$ catalysts indicated that the mesoporous features of the FDU-14 mesopolymer were retained. The Pt/ $/ \mathrm{Al}_{2} \mathrm{O}_{3} @$ FDU-14 catalysts were used in the asymmetric hydrogenation of ethyl pyruvate after they were chirally modified with cinchonidine. For $\mathrm{Al}_{2} \mathrm{O}_{3}$ loading from $5 \%$ to $15 \%, \mathrm{Al}_{2} \mathrm{O}_{3}$ was uniformly dispersed inside the mesoporous channels of FDU-14 host. Ethyl pyruvate conversion and their ee values increased with increasing alumina loading, with a highest ee value of $80 \%$. It was suggested that the alumina coating inside the mesoporous channels of FDU-14 decreased the surface electronic density of the FDU-14 mesopolymer so that cinchonidine can be easily adsorbed on the surface of $\mathrm{Pt} / \mathrm{Al}_{2} \mathrm{O}_{3} @$ FDU-14 catalysts. As compared with chirally modified $\mathrm{Pt} / \mathrm{FDU}-14$ catalysts, chirally modified $\mathrm{Pt} / \mathrm{Al}_{2} \mathrm{O}_{3} @$ FDU-14 catalysts gave higher ee values.
\end{abstract}

Key words: platinum; cinchonidine; ethyl pyruvate; asymmetric hydrogenation; periodic mesoporous resol; mesoporous alumina composite

Received 7 June 2011. Accepted 10 August 2011.

*Corresponding author.Tel/Fax: +86-21-62238590; E-mail: xhli@chem.ecnu.edu.cn

This work was supported by the National Natural Science Foundation of China (20703018), the Shanghai Rising-Star Program (08QA1402700), and the National Basic Research Program of China (973 Program, 2006CB202508).

English edition available online at Elsevier ScienceDirect (http://www.sciencedirect.com/science/journal/18722067). 
手性化合物广泛应用于医药、农药、功能材料 和香料等领域中. 在众多手性化合物的合成方法中, 潜手性化合物的多相不对称催化氢化具有手性增 殖、高光学选择性、经济性和易于工业化等优点, 因 而成为手性药物工业制备中最具有发展前途的研究 领域之一. 目前应用较为成功的催化剂为手性修饰 剂 (如酒石酸和金鸡纳碱) 修饰的金属 (如 $\mathrm{Ni}, \mathrm{Pt}$, Pd) 催化剂 ${ }^{[1]}$. 而金鸡纳生物碱修饰的 Pt 催化剂上 $\alpha$-位官能化潜手性羰基化合物的不对称氢化反应是 多相不对称催化领域的一个重要里程碑, 可以用于 合成许多具有高附加值的精细化学品. 人们对此进 行了大量的研究 ${ }^{[1 ~ 26]}$, 负载 Pt 催化剂的载体从传统 的无机载体如 $\mathrm{Al}_{2} \mathrm{O}_{3}{ }^{[1,2,4,5,7 \sim 9,11 ~ 14,25]}, \mathrm{SiO}_{2}{ }^{[16,17]}$ 和 $\mathrm{Al}_{2} \mathrm{O}_{3} @ \mathrm{SiO}_{2}{ }^{[18,19]}$ 等, 扩展到有机高分子聚合物 ${ }^{[20,21]}$ 、 碳纳米管材料 ${ }^{[22,23]}$ 和介孔碳材料 ${ }^{[24]}$ 等. 商品化 $\mathrm{Pt} / \mathrm{Al}_{2} \mathrm{O}_{3}$ 催化剂因具有较好的催化性能而曾被公认 为此领域的标准催化剂 ${ }^{[7]}$.

有序介孔树脂材料 FDU-14 可由苯酚和甲醛在 表面活性剂三嵌段共聚物 P123 存在的弱碱性条件 下通过有机-有机自组装合成, 具有 Ia3d 对称性 ${ }^{[27,28]}$. 由于其骨架由酚醛树脂组成, 因此具有较强的疏水 性、耐酸碱性和对有机反应底物的亲和性能, 以及较 高的表面电子密度. 除了具备介孔材料的共性 (如较 大的比表面积和规则的孔道) 外, FDU 系列材料的 一些有机官能团使其表现出不同于传统无机载体的 一些特点. 沈亚丽等 ${ }^{[21]}$ 将有机介孔树脂负载的 $\mathrm{Pt}$ 催化剂用于丙酮酸乙酯的不对称加氢反应中, 虽然 产物的光学选择性不高, 但由于 FDU 介孔树脂中苯 环骨架具有的大 $\pi$ 键对贵金属粒子有稳定作用, 所 以催化剂在酸性溶剂中可重复使用 20 次以上.

鉴于 FDU-14 介孔树脂的结构特点和 $\mathrm{Pt} / \mathrm{Al}_{2} \mathrm{O}_{3}$ 催化剂的高反应性能, 本文采用固相研磨法将 $\mathrm{Al}_{2} \mathrm{O}_{3}$ 引入到 FDU-14 孔道内, 制备 FDU-14 孔道限 阈分散的 $\mathrm{Al}_{2} \mathrm{O}_{3}$ 复合材料 $\left(\mathrm{Al}_{2} \mathrm{O}_{3} @ \mathrm{FDU}-14\right)$, 并以它 为载体, 制备负载型 $\mathrm{Pt}$ 催化剂, 经手性分子辛可尼 定修饰后, 用于丙酮酸乙酯的不对称催化氢化反应 中, 以期获得高于 Pt/FDU-14 催化剂的催化性能.

\section{1 实验部分}

\section{1 催化剂的制备与表征}

FDU-14 的合成参见文献 $[27,28]$. 采用固相研
磨法 ${ }^{[29]}$ 制备 $\mathrm{Al}_{2} \mathrm{O}_{3} @ \mathrm{FDU}-14$ (简写为 $x \mathrm{AF}$, 其中 $x$ 为 样品中 $\mathrm{Al}_{2} \mathrm{O}_{3}$ 含量). $\mathrm{FDU}-14$ 原粉与 $\mathrm{Al}\left(\mathrm{NO}_{3}\right)_{3} \cdot 9 \mathrm{H}_{2} \mathrm{O}$ 按照一定比例在玛瑙研钵中充分研磨, 再在真空条 件下于 $350{ }^{\circ} \mathrm{C}$ 焙烧 $3 \mathrm{~h}$ 后, 得到 $\mathrm{Al}_{2} \mathrm{O}_{3} @ \mathrm{FDU}-14$ 复 合材料载体. 采用浸渍法制备 $\mathrm{Pt} / x \mathrm{AF}$ 催化剂 ${ }^{[18]}$. 将氯铂酸 $(\mathrm{Pt} \geq 37 \%)$ 的乙醇溶液或乙醇与水的混合 溶液滴加到载体上, 在电磁搅拌下浸渍 $3 \sim 4 \mathrm{~h}$ 后, 将 多余的溶剂蒸干, 于 $80 \sim 120^{\circ} \mathrm{C}$ 干燥过夜, 在甲酸钠 (纯度 $98 \%$ ) 水溶液中于 $90{ }^{\circ} \mathrm{C}$ 回流 $2 \mathrm{~h}$, 最终得到 $\mathrm{Pt}$ 负载量为 $4 \%$ 的催化剂, 分别记为 $4 \% \mathrm{Pt} / x \mathrm{AF}-\mathrm{E}$ 和 $4 \% \mathrm{Pt} / x \mathrm{AF}-\mathrm{W}+\mathrm{E}$, 其中 $\mathrm{E}$ 或 $\mathrm{W}+\mathrm{E}$ 表示氯铂酸的乙醇 溶液或氯铂酸的乙醇和水的混合溶液.

催化剂通过 X 射线衍射 (XRD, Bruker D8 Advance 型 $\mathrm{X}$ 射线衍射仪, $\mathrm{Cu} K_{\alpha}$ 射线)、 $\mathrm{N}_{2}$ 吸附 (Quantachrome Autosorb-3B 型氮气吸附仪) 和透射 电镜 (TEM, Jeol JEM-2100 型) 等进行表征.

\section{2 丙酮酸乙酯的不对称催化氢化反应}

将 $0.1 \mathrm{~g} \mathrm{Pt} / x \mathrm{AF}$ 催化剂用 $\mathrm{H}_{2}$ 于 $300{ }^{\circ} \mathrm{C}$ 预处理 $2 \mathrm{~h}$ 后, 与 $20 \mathrm{ml}$ 溶剂乙酸、 $10 \mathrm{mg}$ 辛可尼定 (纯度 $99 \%$, TCI 公司) 和 $2 \mathrm{ml}$ 丙酮酸乙酯 (纯度 $98 \%$, Alfa Aesar 公司) 转移到 $100 \mathrm{ml}$ 高压釜中, 通入 $4.0 \mathrm{MPa}$ 纯 $\mathrm{H}_{2}$, 在电磁搅拌 (1000 1200 r/min) 和室温下反应 一段时间后停止. 反应产物经过装有手性色谱柱 (HP19091G-B213，30 $\mathrm{m} \times 0.32 \mathrm{~mm} \times 0.25 \mu \mathrm{m}$, Agilent 公司) 的气相色谱仪 (GC-2014, Shimadzu 公 司) 检测, 用校正归一化法计算混合物组成, 从而得 到丙酮酸乙酯转化率和产物 $(R)-(+)$-乳酸乙酯 ee 值.

\section{2 结果与讨论}

\section{1 催化剂的表征结果}

图 1 为各 $\mathrm{Pt} / x \mathrm{AF}-\mathrm{W}+\mathrm{E}$ 催化剂的 XRD 谱. 可 以看出, $\mathrm{Pt} / x \mathrm{AF}-\mathrm{W}+\mathrm{E}$ 系列催化剂均出现 (211) 和 (220) 晶面衍射峰, 说明催化剂仍保持规整的三维立 方孔道结构, 可见, $\mathrm{Al}_{2} \mathrm{O}_{3} @$ FDU-14 介孔复合材料具 有较高的水热稳定性. 由各样品的广角 XRD 谱可 以看出, 在 $2 \theta=39.7^{\circ}, 46.2^{\circ}$ 和 $67.3^{\circ}$ 处出现 $\operatorname{Pt}(111)$, (200) 和 (220) 晶面衍射峰. 在 $\mathrm{Pt} / 5 \mathrm{AF}-\mathrm{W}+\mathrm{E}$ 和 $\mathrm{Pt} / 10 \mathrm{AF}-\mathrm{W}+\mathrm{E}$ 催化剂上未观察到 $\mathrm{Al}_{2} \mathrm{O}_{3}$ 晶相衍射 峰, 说明载体 $5 \mathrm{AF}$ 和 $10 \mathrm{AF}$ 中 $\mathrm{Al}_{2} \mathrm{O}_{3}$ 高度分散于 FDU-14 介孔孔道中, 没有形成 $\mathrm{Al}_{2} \mathrm{O}_{3}$ 晶相. 当 $\mathrm{Al}_{2} \mathrm{O}_{3}$ 含量达 $15 \%$ 时, 样品在 $2 \theta=37^{\circ}$ 和 $49^{\circ}$ 处出现 

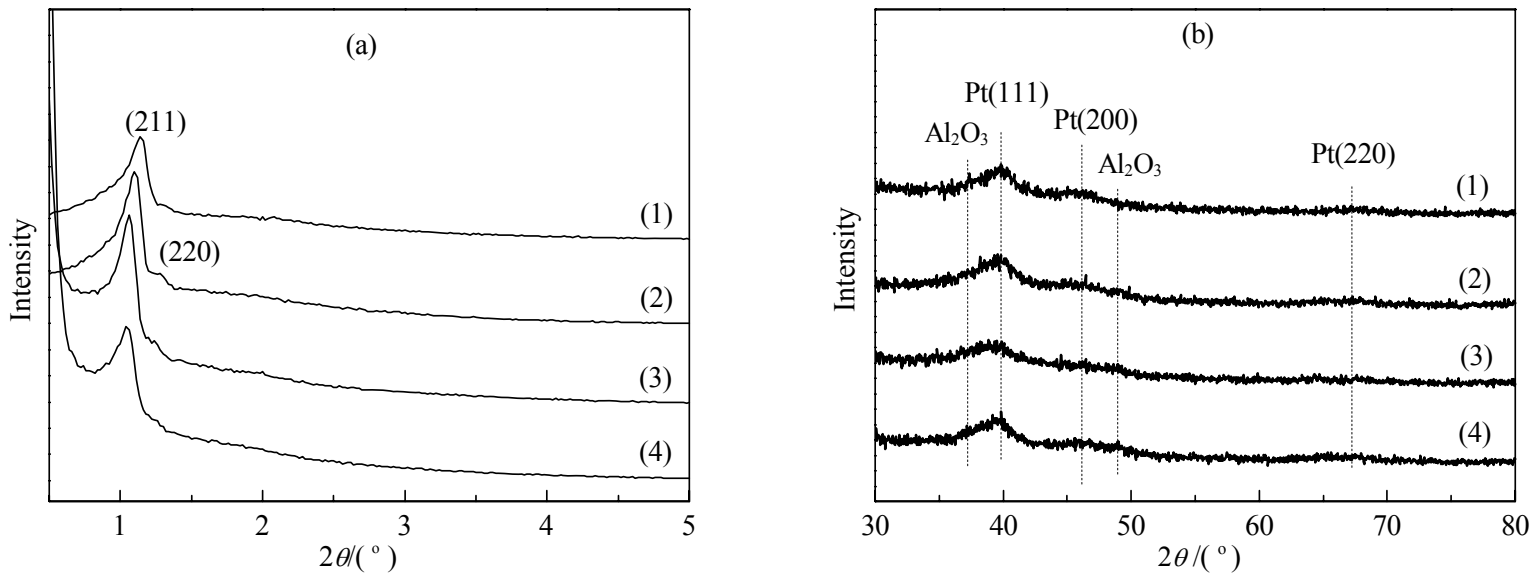

图 1 Pt/xAF-W+E 催化剂的小角和广角 XRD 谱

Fig. 1. Low-angle (a) and wide-angle (b) XRD patterns of Pt/xAF-W+E samples. (1) Pt/FDU-14-W+E; (2) Pt/5AF-W+E; (3) Pt/10AF-W+E; (4) $\mathrm{Pt} / 15 \mathrm{AF}-\mathrm{W}+\mathrm{E} . \mathrm{AF}-\mathrm{Al}_{2} \mathrm{O}_{3} @$ FDU-14; $x$-Alumina mass loading (\%); W+E-Mixture of water and ethanol (1:1, V/V).

了较弱的 $\mathrm{Al}_{2} \mathrm{O}_{3}$ 晶相衍射峰, 表明 $\mathrm{Al}_{2} \mathrm{O}_{3}$ 开始聚集.

图 2 为 FDU-14 和 $x \mathrm{AF}$ 样品的 $\mathrm{N}_{2}$ 吸附-脱附等 温线和孔径分布图. 可以看出, 各样品等温线均为 IV 型, 在 $p / p_{0}$ 为 $0.4 \sim 0.6$ 范围内存在一个 $\mathrm{H} 1$ 型滞 后环, 表明样品具有均一的直型介孔孔道. 另外, FDU-14 和 $x \mathrm{AF}$ 样品的等温线在低压区未完全闭合, 这与文献 $[27,28]$ 结果一致. 样品的孔结构参数见表 1. 可以看出, 随着 $\mathrm{Al}_{2} \mathrm{O}_{3}$ 含量的增加, $x \mathrm{AF}$ 复合材料 的比表面积逐渐降低. $5 \mathrm{AF}$ 与 $10 \mathrm{AF}$ 的孔径为 3.6 $\mathrm{nm}$, 略高于 FDU-14 (3.4 nm). 这可能是由于 $\mathrm{Al}_{2} \mathrm{O}_{3}$ 的引入可抑制焙烧过程中 FDU-14 晶格的收缩, 因 此 $5 \mathrm{AF}$ 和 $10 \mathrm{AF}$ 的 (211) 晶面衍射峰向低角度移动, 对应的 $d$ 值比 FDU-14 的略大. 随着 $\mathrm{Al}_{2} \mathrm{O}_{3}$ 含量进

一步增加, 逐渐超过其在 FDU-14 表面的分散阈值, $\mathrm{Al}_{2} \mathrm{O}_{3}$ 在 FDU-14 孔道内外逐渐形成晶相而占据孔 道, 使得 $\mathrm{Al}_{2} \mathrm{O}_{3} @$ $F D U-14$ 的孔径减小. 当 $\mathrm{Al}_{2} \mathrm{O}_{3}$ 含 量达 $35 \%$ 时, 样品等温线滞后环消失, 说明 FDU-14

表 1 FDU-14 介孔树脂材料和 $x$ AF 复合材料的部分孔结 构参数

Table 1 Physico-chemical parameters of FDU-14 and $x \mathrm{AF}$ composites

\begin{tabular}{lccc}
\hline Sample & $A_{\mathrm{BET}} /\left(\mathrm{m}^{2} / \mathrm{g}\right)$ & $V_{\text {pore }} /\left(\mathrm{cm}^{3} / \mathrm{g}\right)$ & $d / \mathrm{nm}$ \\
\hline FDU-14 & 535 & 0.50 & 3.4 \\
$5 \mathrm{AF}$ & 480 & 0.56 & 3.6 \\
$10 \mathrm{AF}$ & 383 & 0.36 & 3.6 \\
$15 \mathrm{AF}$ & 373 & 0.33 & 3.3 \\
$25 \mathrm{AF}$ & 364 & 0.35 & 3.3 \\
$35 \mathrm{AF}$ & 168 & 0.16 & 2.8 \\
\hline
\end{tabular}
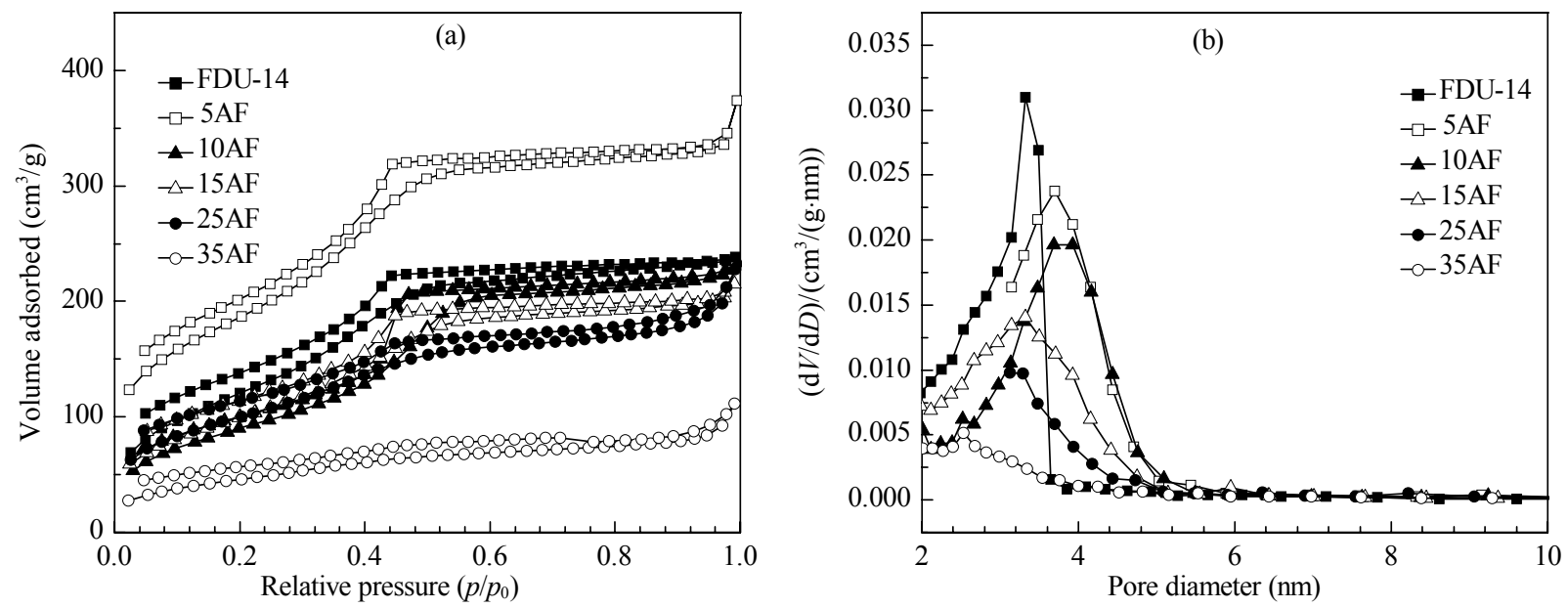

图 2 FDU-14 和 $x A F$ 复合材料的 $N_{2}$ 吸附-脱附曲线和孔径分布图

Fig. 2. $\mathrm{N}_{2}$ adsorption isotherms (a) and pore size distributions (b) of FDU-14 and $x \mathrm{AF}$ composites. 
孔道己经被过量的 $\mathrm{Al}_{2} \mathrm{O}_{3}$ 包埋或封堵, 使其比表面 积、孔体积及孔径都大幅度降低.

图 3 为 $\mathrm{Pt} / x \mathrm{AF}-\mathrm{W}+\mathrm{E}$ 催化剂的 TEM 照片. 可 以看出, 载体中 $\mathrm{Al}_{2} \mathrm{O}_{3}$ 含量较低时, 催化剂三维立方 介孔结构特征明显, Pt 粒子高度分散, 其粒径为 3 4 $\mathrm{nm}$, 没有观察到 $\mathrm{Al}_{2} \mathrm{O}_{3}$ 晶相, 说明 $\mathrm{Al}_{2} \mathrm{O}_{3}$ 在 FDU-14 的孔道内高度分散. 当 $\mathrm{Al}_{2} \mathrm{O}_{3}$ 含量达 $15 \%$ 时, 出现 $\mathrm{Al}_{2} \mathrm{O}_{3}$ 的针状晶体, 将 FDU-14 的部分孔道包埋. 这 与 XRD 和 $\mathrm{N}_{2}$ 吸附结果一致. 这可能是因为 $\mathrm{Al}_{2} \mathrm{O}_{3}$ 与 FDU-14 的孔壁之间相互作用很弱, 焙烧过程导 致 $\mathrm{Al}_{2} \mathrm{O}_{3}$ 聚集.

\section{2 手性修饰的 $\mathrm{Pt} / \mathrm{xAF}$ 催化剂上丙酮酸乙酯的不} 对称催化氢化反应

$\mathrm{Pt} / x \mathrm{AF}$ 催化剂经过手性分子辛可尼定修饰后, 用于丙酮酸乙酯的不对称催化氢化反应 (反应式见 图式 1), 反应结果列于表 2. 可以看出, 经手性修饰 后 Pt/FDU-14-W+E 催化剂上底物转化率和产物的 ee 值分别为 $100 \%$ 和 $62 \%$. 随着载体中 $\mathrm{Al}_{2} \mathrm{O}_{3}$ 含量 增至 15\% 时, 催化剂的光学选择性逐渐增加至 $80 \%$ ee; 至 $25 \%$ 时, 催化剂活性和光学选择性均下降, 分 别为 $82.9 \%$ 和 $62.7 \%$ ee. 当载体中 $\mathrm{Al}_{2} \mathrm{O}_{3}$ 含量达 $35 \%$ 时, 催化剂性能进一步下降, 丙酮酸乙酯转化率
表 2 手性修饰的 $\mathrm{Pt} / x \mathrm{AF}$ 催化剂上丙酮酸乙酯不对称氢化 反应结果

Table 2 Conversions of ethyl pyruvate and ee values of $(R)-(+)$-ethyl lactate obtained with Pt catalysts modified with cinchonidine

\begin{tabular}{lcc}
\hline Catalyst & Conversion (\%) & ee (\%) \\
\hline Pt/FDU-14-W+E & 100 & 62.0 \\
Pt/5AF-W+E & 100 & 71.0 \\
Pt/10AF-W+E & 100 & 73.0 \\
Pt/15AF-W+E & 99.7 & 80.0 \\
Pt/25AF-W+E & 82.9 & 67.0 \\
Pt/35AF-W+E & 12.1 & 33.0 \\
Pt/15AF-E & 99.8 & 71.7 \\
Pt/25AF-E & 99.5 & 72.7 \\
Pt/35AF-E & 79.5 & 66.5 \\
\hline
\end{tabular}

Reaction conditions: $0.1 \mathrm{~g} \mathrm{Pt} / x \mathrm{AF}$ catalyst pretreated in a hydrogen flow at $300{ }^{\circ} \mathrm{C}$ for $2 \mathrm{~h}, 0.01 \mathrm{~g}$ cinchonidine, $2 \mathrm{ml}$ ethyl pyruvate, $20 \mathrm{ml}$ acetic acid, $4.0 \mathrm{MPa} \mathrm{H}_{2}, 25^{\circ} \mathrm{C}, 30 \mathrm{~min}, 1000-1200 \mathrm{r} / \mathrm{min}$.

和产物光学选择性仅分别为 $12.1 \%$ 和 $33 \%$ ee.

手性修饰剂辛可尼定主要通过喹啉环的大 $\pi$ 键 或 $\mathrm{N}$ 原子的孤对电子吸附在 Pt 粒子表面进行手性 诱导 ${ }^{[8]}$, 而 FDU-14 介孔树脂骨架由聚合多苯环组 成, 表面具有较多的 $\pi$ 电子, 它们与辛可尼定的喹啉 环产生排斥作用, 不利于辛可尼定在 Pt 粒子表面的 吸附, 因此 $\mathrm{Pt} / \mathrm{FDU}-14-\mathrm{W}+\mathrm{E}$ 的手性诱导能力较低. $\mathrm{Al}_{2} \mathrm{O}_{3}$ 的引入使得 FDU-14 表面形成高分散的 $\mathrm{Al}_{2} \mathrm{O}_{3}$
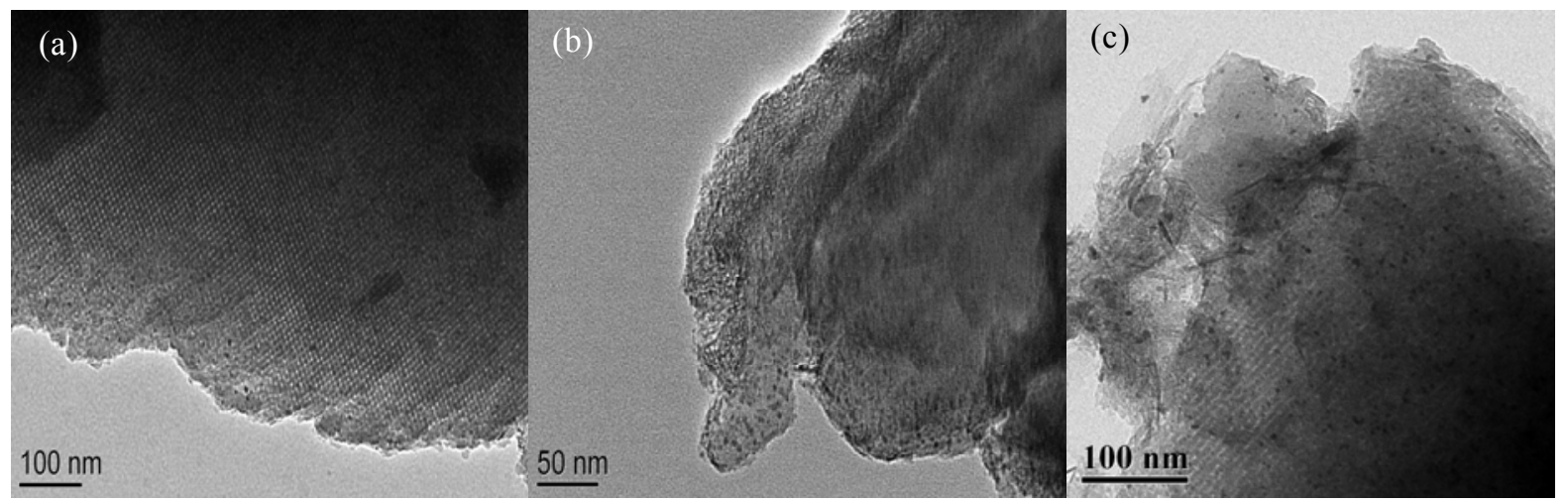

图 3 Pt/xAF-W+E 催化剂的 TEM 照片

Fig. 3. TEM images of Pt/5AF-W+E (a), Pt/10AF-W+E (b), and Pt/15AF-W+E (c).

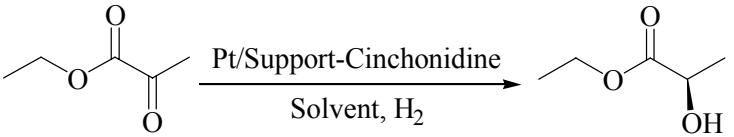

Ethyl pyruvate

$(R)-(+)$-Ethyl lactate

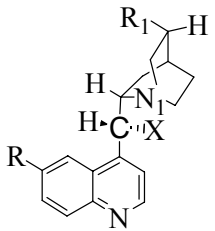

Cinchonidine

图式 1 丙酮酸乙酯在 Pt/xAF 催化剂上的不对称氢化反应

Scheme 1. Chiral hydrogenation of ethyl pyruvate on chirally modified $\mathrm{Pt} / x \mathrm{AF}$ catalysts. 
涂层, 可遮盖 FDU-14 表面的 $\pi$ 电子, 且可与 Pt 粒 子产生较强的相互作用, 从而有利于辛可尼定在 $\mathrm{Pt}$ 粒子表面的吸附, 因而 $(R)-(+)$-乳酸乙酯的光学选择 性增加. 尽管当 $x \mathrm{AF}$ 样品浸渍于 $\mathrm{H}_{2} \mathrm{PtCl}_{6}$ 乙醇和水 混合溶液中时, $\mathrm{PtCl}_{6}{ }^{2-}$ 会均匀分散在 $x \mathrm{AF}$ 复合材料 表面, 然而当 $x \mathrm{AF}$ 载体中 $\mathrm{Al}_{2} \mathrm{O}_{3}$ 含量达 $25 \%$ 以上 时, 其大部分以晶相存在, 占据了基底 FDU-14 孔道, 导致样品部分孔道被堵塞, 因而比表面积大幅度下 降. 因此, Pt/25AF-W+E 和 Pt/35AF-W+E 催化剂上 丙酮酸乙酯的不对称催化氢化反应中反应物和产物 的扩散受限, 催化剂性能下降.

我们还考察了氯铂酸的分散介质对相应催化剂 上丙酮酸乙酯不对称氢化反应的影响. 当复合材料 载体中 $\mathrm{Al}_{2} \mathrm{O}_{3}$ 含量相当时, 以乙醇为分散介质时, 相 应催化剂活性高于以乙醇-水溶液为分散介质的. $\mathrm{Pt} / 35 \mathrm{AF}-\mathrm{E}$ 催化剂经辛可尼定修饰后, 丙酮酸乙酯转 化率和光学选择性分别为 $79.5 \%$ 和 $66.5 \%$ ee. 由于 FDU-14 具有较强的疏水性, 所以当 xAF 样品浸渍 于 $\mathrm{H}_{2} \mathrm{PtCl}_{6}$ 的乙醇溶液时, $\mathrm{PtCl}_{6}^{2-}$ 主要分布在 FDU-14 外表面. 尽管 $25 \mathrm{AF}$ 和 $35 \mathrm{AF}$ 中 $\mathrm{Al}_{2} \mathrm{O}_{3}$ 晶体 已经覆盖了 FDU-14 的部分孔道, 但在浸渍 Pt 的过 程中, 大部分 Pt 粒子可能分布在载体外表面 ${ }^{[19]}$. 因 此, 即使因 $\mathrm{Al}_{2} \mathrm{O}_{3}$ 含量较高而可能导致 FDU-14 孔 道堵塞, 反应底物也可以与分布在孔道外表面的 $\mathrm{Pt}$ 粒子接触并进行加氢反应, 因而催化活性和光学选 择性较高.

\section{3 结论}

采用固相研磨法将一定量的 $\mathrm{Al}_{2} \mathrm{O}_{3}$ 涂覆到有序 介孔树脂材料 FDU-14 孔道内, 制备了 $\mathrm{Al}_{2} \mathrm{O}_{3} @$ FDU-14 介孔复合材料, 它不仅具备基底材料的有序 介孔结构、高比表面积和可调的孔径, 而且还具备了 $\mathrm{Al}_{2} \mathrm{O}_{3}$ 高催化性能. $\mathrm{Al}_{2} \mathrm{O}_{3}$ 的引入可以降低 FDU-14 表面的电子密度, 有利于手性修饰剂的吸附, 从而提 高复合材料负载的 Pt 催化剂上丙酮酸乙酯不对称 氢化反应中的光学选择性. 固相研磨法也可用来制 备其它固体复合材料, 其负载的贵金属催化剂有望 在催化氢化合成反应中表现出较高的催化性能.

\section{参考文 献}

1 Mallat T, Orglmeister E, Baiker A. Chem Rev, 2007, 107:
4863

2 Wehrli J T, Baiker A, Monti D M, Blaser H U. J Mol Catal, 1990, 61: 207

3 Blaser H U, Jalett H P, Müller M, Studer M. Catal Today, 1997, 37: 441

4 Zuo X B, Liu H F, Yue Ch. J Mol Catal A, 1999, 147: 63

5 Török B, Felföldi K, Balázsik K, Bartók M. Chem Commun, 1999: 1725

6 Bhaduri S, Lahiri G K, Munshi P, Munshi P, Mukesh D. Catal Lett, 2000, 65: 61

7 Studer M, Blaser H U, Exner C. Adv Syn Catal, 2003, 345: 45

8 Bürgi T, Baiker A. Acc Chem Res, 2004, 37: 909

9 Balázsik K, Bartok M. J Mol Catal A, 2004, 219: 383

10 姜鹏, 李晓红, 关业军, 应品良, 李灿. 分子催化 (Jiang P, Li X H, Guan Y J, Ying P L, Li C. J Mol Catal (China)), 2004, 18: 381

11 Bartok M. Curr Org Chem, 2006, 10: 1533

12 Balázsik K, Szöri K, Felföldi K, Török B, Bartók M. Chem Commun, 2000: 555

13 韩涤非, 杨启华, 李灿. 催化学报 (Han D F, Yang Q H, Li C. Chin J Catal), 2008, 29: 789

14 Balázsik K, Szöri K, Szöllösi G, Bartók M. Chem Commun, 2011, 47: 1551

15 Tálas E, Margitfalvi J L, Egyed O. J Catal, 2009, 266: 191

16 Török B, Szöllösi G, Balázsik K, Felföldi K, Kun I, Bartók M. Ultrasonics Sonochem, 1999, 6: 97

17 Griffiths S P, Johnson P, Wells P B. Appl Catal A, 2000, 191: 193

18 陈志坚, 李晓红, 李灿. 催化学报 (Chen Zh J, Li X H, Li C. Chin J Catal), 2011, 32: 155

19 Wang H N, Li X H, Wang Y M, Wu P. ChemCatChem, 2010, 2: 1303

20 Li X H, Shen Y L, Xing R, Liu Y M, Wu H H, He M Y, Wu P. Catal Lett, 2008, 122: 325

21 沈亚丽, 李晓红, 宋丽英, 王红娜, 吴鹏. 高等学校化学 学报 (Shen Y L, Li X H, Song L Y, Wang H N, Wu P. Chem J Chin Univ), 2009, 30: 1375

22 Chen Z J, Guan Z H, Li M R, Yang Q H, Li C. Angew Chem, Int Ed, 2011, 50: 4913

23 Xing L, Du F, Liang J J, Chen Y S, Zhou Q L. J Mol Catal A, 2007, 276: 191

24 Li B, Li X H, Wang H N, Wu P. J Mol Catal A, 2011, 345: 81

25 陶国忠, 卢冠忠, 郭耘, 王艳芹, 郭杨龙, 张志刚, 刘晓 晖, 王筑松. 催化学报 (Tao G Z, Lu G Z, Guo Y, Wang Y Q, Guo Y L, Zhang Zh G, Liu X H, Wang Y S. Chin J (atal), 2009, 30: 391

26 彭宗海, 马梦林, 付海燕, 陈华, 李贤钧. 催化学报 (Peng Z H, Ma M L, Fu H Y, Chen H, Li X J. Chin J Catal), 2010, 31: 191

27 Zhang F Q, Meng Y, Gu D, Yan Y, Yu Ch Zh, Tu B, Zhao D Y. J Am Chem Soc, 2005, 127: 13508

28 Zhang F Q, Meng Y, Gu D, Yan Y, Chen Zh X, Tu B, Zhao 
D Y. Chem Mater, 2006, 18: 5279

29 Wang Y M, Wu Zh Y, Shi L Y, Zhu J H. Adv Mater, 2005, 17: 323

\section{英 译 文 \\ English Text}

Heterogeneous asymmetric catalysis is one of the most promising methods for the industrial preparation of chiral drugs because of its high optical yield, easy industrialization, and other advantages. Chiral compounds are used in the synthesis of pharmaceuticals, pesticides, perfumes, food additivies, and other functional materials. Among the methods for the synthesis of chiral compounds, the asymmetric hydrogenation of prochiral compounds is popular. Chiral modifiers, such as tartaric acid and cinchona alkaloids, are used to modify noble metal catalysts such as $\mathrm{Ni}, \mathrm{Pt}$, and Pd to give some typical successful examples of heterogeneous asymmetric hydrogenation systems [1]. Cinchona alkaloid modified platinum for the asymmetric hydrogenation of $\alpha$-functionalized prochiral carbonyl compounds is an important milestone of this field. It can be used for the synthesis of many high value-added fine chemicals, and many researchers have worked on it [1-26]. Traditional inorganic materials such as $\mathrm{Al}_{2} \mathrm{O}_{3}$ [1,2,4,5,7-9, 11-14,25], $\mathrm{SiO}_{2}$ [16,17], and $\mathrm{Al}_{2} \mathrm{O}_{3} @ \mathrm{SiO}_{2}$ [18,19] were originally used to support the Pt nanoparticles. Recently, organic polymers [20,21], carbon nanotubes [22,23], and mesoporous carbon materials [24] have been investigated as the support for the entrapment of $\mathrm{Pt}$ nanoparticles. The commercial $\mathrm{Pt} / \mathrm{Al}_{2} \mathrm{O}_{3}$ catalyst is recognized as a standard catalyst in this area owing to its excellent catalytic property [7].

FDU-14 periodic mesoporous resols with the Ia3d symmetry was first reported by Zhang et al. [27,28]. It is synthesized from the organic-organic self-assembly of triblock copolymers with resols (phenol and formaldehyde) via a simple dilute aqueous strategy under basic conditions. Because the framework is composed of phenolic resins, it has strong hydrophobicity and good stability even under acidic and basic conditions, a high affinity for the substrates, and a high surface electronic density. In addition to their features of a mesoporous material, such as a large surface area and uniform mesopores, FDU-type mesoporous resols also contain a number of organic functional groups that have different characteristics from the traditional inorganic materials. In our previous work, we found that Pt nanoparticles entrapped in the FDU-15 periodic mesopolymer by a simple impregnation method were active in the catalysis of the asymmetric hydrogenation of ethyl pyruvate after they were chirally modified with cinchonidine, and they showed moderate enantioselectivity. In addition, the Pt/FDU-15 catalyst could be reused in acetic acid for over 20 times without any loss of activity or enantioselectivity. This is because the benzene rings of the mesoporous FDU-15 resols can stabilize the Pt nanoparticles through a $\pi$ donation interaction [21].

In this work, a series of $\mathrm{Al}_{2} \mathrm{O}_{3} @$ FDU-14 composites with different loadings of alumina were prepared using a solid-state grinding method to take advantage of both the FDU-14 periodic mesoporous resols and $\mathrm{Al}_{2} \mathrm{O}_{3}$. This composite as the support for $\mathrm{Pt}$ nanoparticles in the heterogeneous asymmetric hydrogenation of ethyl pyruvate has been rarely reported. The $\mathrm{Pt} / \mathrm{Al}_{2} \mathrm{O}_{3} @$ FDU-14 catalysts were expected to give a better higher catalytic performance than the Pt/FDU-14 catalyst in the asymmetric hydrogenation of ethyl pyruvate after chiral modification with cinchonidine.

\section{Experimental}

\subsection{Catalyst preparation and characterization}

The FDU-14 periodic mesoporous resols were synthesized using a procedure in the literature [27,28]. A series of $\mathrm{Al}_{2} \mathrm{O}_{3} @$ FDU-14 composites with different alumina loadings (denoted as $x \mathrm{AF}$, where $x$ represents the alumina mass loading) were prepared using a solid-state grinding method [29]. The FDU-14 powder and $\mathrm{Al}\left(\mathrm{NO}_{3}\right)_{3} \cdot 9 \mathrm{H}_{2} \mathrm{O}$ were then mixed and ground in an agate mortar, followed by calcination under vacuum at $350{ }^{\circ} \mathrm{C}$ for $3 \mathrm{~h}$, and finally the $\mathrm{Al}_{2} \mathrm{O}_{3} @$ FDU-14 composites were prepared. The $\mathrm{Pt} / x \mathrm{AF}$ catalysts were prepared by an impregnation method [19]. The $\mathrm{Al}_{2} \mathrm{O}_{3} @$ FDU-14 composites were impregnated with $\mathrm{H}_{2} \mathrm{PtCl}_{6}$ (Pt wt $\% \geq 37 \%$ ) dissolved in ethanol or in a $1: 1 \mathrm{~V} / \mathrm{V}$ mixture of water and ethanol, and stirred for 4-6 h. Then the mixture was evaporated to remove excess solvent, which was followed by drying at $80-120{ }^{\circ} \mathrm{C}$ overnight. Subsequently, the catalyst precursor was reduced in an aqueous solution of sodium formate at $90{ }^{\circ} \mathrm{C}$ to obtain the $4 \mathrm{wt} \% \mathrm{Pt} / x \mathrm{AF}$ catalyst. To distinguish the different medium used for the Pt precursor, the $4 \mathrm{wt} \% \mathrm{Pt} / x \mathrm{AF}$ catalysts were designated as $\mathrm{Pt} / x \mathrm{AF}-\mathrm{E}$ or $\mathrm{Pt} / x \mathrm{AF}-\mathrm{W}+\mathrm{E}$, where $\mathrm{E}$ or $\mathrm{W}+\mathrm{E}$ stands for the ethanol solution of $\mathrm{H}_{2} \mathrm{PtCl}_{6}$ or the $1: 1 \mathrm{~V} / \mathrm{V}$ mixture solution of water and ethanol containing $\mathrm{H}_{2} \mathrm{PtCl}_{6}$.

The $\mathrm{Pt} / x \mathrm{AF}$ ctalysts were characterized by X-ray diffraction (XRD, Bruker D8 Advance X-ray diffractometer, $\mathrm{Cu} K_{\alpha}$ radiation), $\mathrm{N}_{2}$ adsorption (Quantachrome Autosorb-3B system), and transmission electron microscopy (TEM, Jeol JEM-2100 electromicroscope with an acceleration voltage of $200 \mathrm{kV})$.

\subsection{Asymmetric hydrogenation of ethyl pyruvate}


The $4 \mathrm{wt} \% \mathrm{Pt} / x \mathrm{AF}$ catalyst $(0.1 \mathrm{~g})$ was pretreated in a hydrogen flow at $300{ }^{\circ} \mathrm{C}$ for $2 \mathrm{~h}$ before use. The catalyst was then mixed with $20 \mathrm{ml}$ acetic acid, $10 \mathrm{mg}$ cinchonidine (99\%, purchased from TCI) and $2 \mathrm{ml}$ ethyl pyruvate $(98 \%$, purchased from Alfa Aesar). The mixture was transferred to a $100 \mathrm{ml}$ autoclave. The hydrogenation reaction was performed with magnetic stirring (1000-1200 r/min) at room temperature and it began when 4.0 $\mathrm{MPa}$ of hydrogen was introduced. The reaction was stopped after $30 \mathrm{~min}$ and the products were analyzed by GC-FID (GC-2014, Shimadzu Co.) equipped with a chiral capillary column (HP19091G-B213, $30 \mathrm{~m} \times 0.32 \mathrm{~mm} \times 0.25 \mu \mathrm{m}$, Agilent Co.). The optical yield was expressed as the enantiomeric excess (ee) of $(R)-(+)$-ethyl lactate.

\section{Results and discussion}

\subsection{Catalyst characterization results}

Figure 1 shows the low-angle and wide-angle XRD patterns of the $\mathrm{Pt} / x \mathrm{AF}-\mathrm{W}+\mathrm{E}$ catalysts. All the $\mathrm{Pt} / x \mathrm{AF}-\mathrm{W}+\mathrm{E}$ catalysts gave diffraction peaks that were indexed as the (211) and (220) planes of the FDU-14 host. This demonstrated that all the $\mathrm{Pt} / x \mathrm{AF}-\mathrm{W}+\mathrm{E}$ catalysts retained the similar three-dimensional cubic meso-structure as the FDU-14 host even after the support was soaked in $\mathrm{H}_{2} \mathrm{PtCl}_{6}$ solution and sodium formate aqueous solution for several hours. This also implied that the $\mathrm{Al}_{2} \mathrm{O}_{3}$ @FDU-14 mesoporous composites had good hydrothermal stability. The wide-angle XRD patterns showed weak diffraction peaks at $2 \theta=39.7^{\circ}, 46.2^{\circ}$, and $67.3^{\circ}$ that were indexed as the $\mathrm{Pt}(111), \operatorname{Pt}(200)$, and $\mathrm{Pt}(220)$ planes, respectively. In the diffraction patterns of the $\mathrm{Pt} / 5 \mathrm{AF}-\mathrm{W}+\mathrm{E}$ and $\mathrm{Pt} / 10 \mathrm{AF}-\mathrm{W}+\mathrm{E}$ catalysts, we did not observe the diffraction peaks of the $\mathrm{Al}_{2} \mathrm{O}_{3}$ crystalline phase, indicating that the $\mathrm{Al}_{2} \mathrm{O}_{3}$ in $5 \mathrm{AF}$ and $10 \mathrm{AF}$ was uniformly dispersed inside the FDU-14 mesoporous channels without the formation of an $\mathrm{Al}_{2} \mathrm{O}_{3}$ crystalline phase. When the $\mathrm{Al}_{2} \mathrm{O}_{3}$ loading reached $15 \mathrm{wt} \%$, weak diffraction peaks of the $\mathrm{Al}_{2} \mathrm{O}_{3}$ crystalline phase could be observed at $2 \theta=37^{\circ}$ and $49^{\circ}$, suggesting that $\mathrm{Al}_{2} \mathrm{O}_{3}$ had began to aggregate at this loading.

Figure 2 shows the nitrogen adsorption-desorption isotherms and Barrett-Joyner-Halenda (BJH) pore size distributions of FDU-14 and $x \mathrm{AF}$ mesoporous composites. These samples exhibited typical Type IV isotherms and showed clear H1-type hysteresis loops in the $p / p_{0}=0.4-0.6$ region, indicating that the samples had a uniform mesoporous structure. The nitrogen adsorption-desorption isotherms of FDU-14 and $x \mathrm{AF}$ samples in the low pressure region were not completely closed, which is consistent with the mesopolymer materials reported in the literature $[27,28]$. The pore structure parameters of the samples are shown in
Table 1. With the increasing of the $\mathrm{Al}_{2} \mathrm{O}_{3}$ loading, the BET surface area of the $x \mathrm{AF}$ composite materials decreased. The pore diameters of $5 \mathrm{AF}$ and $10 \mathrm{AF}$ were $3.6 \mathrm{~nm}$, which was slightly larger than that of FDU-14 (3.4 nm). The introduction of $\mathrm{Al}_{2} \mathrm{O}_{3}$ into the FDU-14 mesopores can inhibit FDU-14 framework shrinkage when it was calcined at a high temperature to remove the template agent, thus the $2 \theta$ diffraction angle of the (211) crystal plane for $5 \mathrm{AF}$ and 10 AF was slightly smaller, and the corresponding $d$ value was slightly larger than that of FDU-14.

With the further increase of the $\mathrm{Al}_{2} \mathrm{O}_{3}$ loading, the alumina amount exceeded the dispersion threshold of FDU-14, thus the $\mathrm{Al}_{2} \mathrm{O}_{3}$ crystalline phase was gradually formed inside and outside the FDU-14 mesopores, which reduced the pore volume of the FDU-14 resols and the pore diameter of $15 \mathrm{AF}$ and $25 \mathrm{AF}$ decreased to $3.3 \mathrm{~nm}$. When the $\mathrm{Al}_{2} \mathrm{O}_{3}$ loading was increased to $35 \%$, the hysteresis loop in the nitrogen adsorption-desorption isotherms disappeared, demonstrating that the mesopores of FDU-14 had been blocked by the excessive $\mathrm{Al}_{2} \mathrm{O}_{3}$, and the BET surface area, pore volume, and pore diameter of $35 \mathrm{AF}$ were much decreased.

Figure 3 shows the TEM images of some $\mathrm{Pt} / x \mathrm{AF}-\mathrm{W}+\mathrm{E}$ catalysts. When the alumina loading was relatively low $(\mathrm{Pt} / 5 \mathrm{AF}-\mathrm{W}+\mathrm{E}$ and $\mathrm{Pt} / 10 \mathrm{AF}-\mathrm{W}+\mathrm{E}$ catalysts), the features of the three-dimensional mesoporous structure were quite distinct and the Pt nanoparticles were highly dispersed with the average Pt particle size of 3-4 $\mathrm{nm}$. No alumina crystallite was observed, indicating that the alumina was uniformly and highly dispersed inside the mesopores of FDU-14 resols. When the alumina content reached $15 \%$, needle-like alumina crystallites appeared that occupied part of the FDU-14 mesopores. This is consistent with the XRD and nitrogen adsorption characterization of the $x \mathrm{AF}$ composites. This may be due to the weak interaction between alumina and FDU-14 pore walls, such that the aggregation of alumina occured during the calcination to remove the template agent.

\subsection{Asymmetric hydrogenation of ethyl pyruvate on chirally modified Pt/xAF catalysts}

Table 2 shows the results for the asymmetric hydrogenation of ethyl pyruvate with the cinchonidine modified $\mathrm{Pt} / x \mathrm{AF}$ catalysts after $30 \mathrm{~min}$ (Scheme 1). The Pt/FDU-14-W+E catalyst gave $100 \%$ conversion of ethly pyruvate and $62 \%$ ee of $(R)-(+)$-ethyl lactate after it was chirally modified with cinchonidine. The coating of alumina inside the FDU-14 mesopores improved the chiral activity of the chirally modified Pt/xAF catalysts. With the increase of the alumina loading from zero to $15 \%$, the chiral activity of the chirally modified $\mathrm{Pt} / x \mathrm{AF}$ catalysts was gradually enhanced. As a result, the cinchonidine modified $\mathrm{Pt} / 15 \mathrm{AF}-\mathrm{W}+\mathrm{E}$ catalyst gave an $80 \%$ ee value for 
$(R)$-(+)-ethyl lactate. When the alumina loading was increased to $25 \%$, the conversion and enantioselectivity both decreased to give only $82.9 \%$ conversion and $62.7 \%$ ee value. The catalytic performance of the chirally modified $\mathrm{Pt} / 35 \mathrm{AF}-\mathrm{W}+\mathrm{E}$ catalyst was further decreased to give $12.1 \%$ conversion and $33 \%$ ee value.

The chiral reaction of the cinchonidine modified $\mathrm{Pt}$ catalyst is through the $\pi$ donation of the quinoline ring or by adsorption through the $\mathrm{N}$ atom lone pair electrons of quinoline on the Pt surface [8]. The polyaromatic rings with a high electronic density in the FDU-14 resol framework will hinder the adsorption of cinchonidine on the Pt surface by a repulsion interaction. Therefore, the chiral activity of he Pt/FDU-14-W+E catalyst was relatively low. The introduction of alumina inside the FDU-14 mesopores will produce a highly dispersed film that block the $\pi$ electrons of FDU-14. Therefore, a strong interaction between the Pt nanoparticles and the highly dispersed alumina would benefit the adsorption of cinchonidine to result in high enantioselectivity. Although $\mathrm{PtCl}_{6}{ }^{2-}$ species can be uniformly dispersed on the $x \mathrm{AF}$ composties surface when the composites were impreganated with the mixture solution of $\mathrm{H}_{2} \mathrm{PtCl}_{6}$, after the alumina loading reached above $25 \mathrm{wt} \%$, alumina crystallites formed will occupy and block the mesopores of $x \mathrm{AF}$. Thus, the specific surface areas of these $x \mathrm{AF}$ composites were strongly decreased (see the relevant paramters in Table 1). Therefore, the mass transport of reactant and product will be slow in the asymmetric hydrogenation of ethyl pyruvate catalyzed by cinchonidine modified $\mathrm{Pt} / 25 \mathrm{AF}-\mathrm{W}+\mathrm{E}$ and $\mathrm{Pt} / 35 \mathrm{AF}-\mathrm{W}+\mathrm{E}$ catalysts, resulting in the low catalytic results with these two catalysts.

In order to investigate the effect of the dispersion medium on the reaction results, we also changed the medium used to dissolve $\mathrm{H}_{2} \mathrm{PtCl}_{6}$. Compared with the $\mathrm{Pt} / x \mathrm{AF}-\mathrm{W}+\mathrm{E}$ catalysts, the $\mathrm{Pt} / x \mathrm{AF}-\mathrm{E}$ catalysts with the same alumina loading pre- pared using the ethanol solution of $\mathrm{H}_{2} \mathrm{PtCl}_{6}$ showed slightly higher activities for the asymmetric hydrogenation of ethyl pyruvate. The chirally modified $\mathrm{Pt} / 35 \mathrm{AF}-\mathrm{E}$ catalyst gave $79.5 \%$ conversion and $66.5 \%$ ee value. The $\mathrm{PtCl}_{6}{ }^{2-}$ species were mostly dispersed on the outer surface of the $x \mathrm{AF}$ composites when the $x \mathrm{AF}$ composites were impregnated with the ethanol solution of $\mathrm{H}_{2} \mathrm{PtCl}_{6}$ due to the strong hydrophobicity of the $x \mathrm{AF}$ composites [19]. It appeared that the reactant could still be adsorbed and hydrogenated on the surface of Pt nanoparticles dispersed on the outer surface of $x \mathrm{AF}$ composites to give fairly high activity and enantioselectivity, even when alumina crystallites in $25 \mathrm{AF}$ and $35 \mathrm{AF}$ had already occupied the mesopores of the FDU-14 resols.

\section{Conclusions}

$\mathrm{Al}_{2} \mathrm{O}_{3} @$ FDU-14 mesoporous composites were prepared by coating alumina inside the mesopores of FDU-14 resols using a solid-state grinding method. The composites had the structural features of a periodic mesoporous material such as ordered mesopores, high surface area, and tunable pore size, and also had the high catalytic activity of alumina. The introduction of alumina inside the mesopores of FDU-14 resols decreased the electronic density of the walls of the FDU-14 resols so that the chiral modifier was easily adsorbed on the catalyst surface. Thus, the chiral reaction activity of the chirally modified Pt catalyst supported on the composites was improved. The solid-state grinding method can also be used to prepare other solid composites. The composite-supported Pt catalysts after modification with a chiral modifier are expected to show high enantioselectivity in water.

Full-text paper available online at Elsevier ScienceDirect http://www.sciencedirect.com/science/journal/18722067 